\title{
The Case of the Harmony Basin Grazing Allotment
}

\author{
Barry R. Munsell, Larry W. Van Tassell* and Michael A. Smith
}

\begin{abstract}
The Harmony Basin Grazing Allotment, located in Wyoming, is administered by the U.S. Forest Service. In 1991, the USFS issued a Decision Notice for the allotment calling for a $50 \%$ cut in grazing and a conversion of high altitude pastures from cattle (Bos taurus) to sheep (Ovis aries) grazing after a 5yr rest period. The changes were intended to remedy problems found by the USFS with rangelands, wildlife and fish habitat, riparian plant communities, and aspen (Populus tremuloides Michx.) stands within the basin. For the Moon, Pratt, and Sowers families-holders of grazing permits for the allotment - the cuts meant lost pasture for $989 \mathrm{cow}$-calf pairs over the summer grazing season. Citing misinterpretations of biological data and negative economic and social impacts, the grazing permit holders (permittees), led by the Sowers, appealed the Decision Notice to Sid Barnes, High Peaks National Forest supervisor. Barnes granted the stay of the decision and also committed the USFS to participate in a Coordinated Resource Management (CRM) group. The group's goals were to formulate grazing plans to ensure that standards and guidelines mandated in the High Peaks Land and Resource Management Plan of 1983 were met on the grazing allotment while minimizing negative economic and social impacts to the permittees and community. The CRM is an innovative approach to resolving natural resource management. This case serves to introduce the CRM method and gives students the opportunity to experience the CRM method as they discuss and attempt to solve a natural resource conflict.
\end{abstract}

$\mathrm{N}$ ATURAL resource management, especially on public lands in the Rocky Mountain region, is continually besieged with controversy propagated by many groups (Lundburg, 1980; Ross, 1984; Cramer et al., 1993; Borman and Johnson, 1990). Emotions and personality issues often overshadow and supercede technical knowledge and natural resource management principles. In a number of cases, courts of law have eventually settled the disputes and mandated management plans, rarely to the satisfaction of anyone.

Within this climate of conflict, individuals from private, public, and special interest backgrounds have developed an innovative approach to resolving natural resource management conflicts for the benefit of all, including the resource. Called Coordinated Resource Management (CRM) in Wyoming, and by similar names in other Rocky Mountain states, this approach is a proven tool in allowing concerned individuals to work together to more effectively manage natural resources. This case provides insight into the social,

B.R. Munsell and L.W. Van Tassell, Dep. of Agricultural and Applied Economics, Univ. of Wyoming, Laramie, WY 82071-3354; and M.A Smith, Dep. of Renewable Resources, Univ. of Wyoming, Laramie, WY 82071-3354. This material is based on work supported by the USDA Higher Education Challenge Grants Program. Received 26 Feb. 1998 *Corresponding author (vant@uwyo.edu).

Published in J. Nat. Resour. Life Sci. Educ. 28:41-47 (1999) http://www.JNRLSE.org economic, and scientific issues that influence the formulation of grazing management plans for public lands while providing the framework for learning consensus building skills through the CRM method.

\section{THE CASE ${ }^{1}$ (ABRIDGED $\left.{ }^{2}\right)$ \\ Background}

Harmony Basin (Exhibit 1) has always been a land of raw, untamed beauty and rich natural resources. Reaching from the majestic steep sided canyons of lower Harmony Creek, to the snow covered, rocky ridges of Sheep Mountain, Harmony Basin encompasses $>177 \mathrm{~km}^{2}$ of the High Peaks National Forest in the Rocky Mountains of Wyoming.

Once the hunting ground of American Indians, the basin quickly became summer pasture for cattle and sheep as the first ranchers settled in Harmony Creek Valley during the 1880 s. By the end of the 19th century, uncontrolled grazing had severely degraded pastures within Harmony Basin and other high country areas across the west. As a result of rangeland abuse, the USFS was established in 1905 and a forage allotment system was initiated (Holechek et al., 1989).

In Harmony Basin, the USFS forage allotment system resulted in grazing permits being issued to area ranches for 1400 cow-calf pairs and 3000 sheep with the grazing season running from 1 July to 10 October. Ranches receiving permits had to: (i) have base property in the area; (ii) show prior use of grazing in the area; and (iii) have feed resources available when livestock were not on USFS land. ${ }^{3}$

Edward J. Hampton and his cousin Joseph established the Round Top Ranch at the mouth of Harmony Creek Canyon in 1928. A USFS permit to graze 1000 cow-calf pairs in Harmony Basin accompanied the land they purchased. To expand operations, the Hamptons purchased an additional 3000-head sheep permit for Harmony Basin in 1938 from a neighboring ranch. When the grazing permit exchanged ownership, the USFS reduced the permit to 2000 head. Due to increasing losses of sheep to predation and the general unprofitability of the sheep business, the permit was converted to cattle at the rate of one cow for five sheep in 1973 $(1: 5$, cow/sheep). At the same time, the USFS imposed a $20 \%$ reduction. After the conversion, the Hamptons were grazing a total of 1307 cow-calf pairs in the basin over the summer season.

\footnotetext{
${ }^{1}$ At the request of the parties involved names, places, and dates in this case have been disguised.

2 This is an abridgement of the complete case. The complete case consists of 19 pages of text, 131 pages of exhibits, and a 5-page teaching note. Contact the corresponding author to request a copy of the complete case.

${ }^{3}$ For a discussion on the history of public land grazing, see Hage, 1994; Lundburg, 1980; and Ross, 1984.
}

Abbreviations: USFS, U.S. Forest Service; CRM, coordinated resource management; AUM, animal unit month; NEPA, National Environmental Policy Act; EA, environmental assessment; EIS, environmental impact study; BLM, Bureau of Land Management. 
During the period after 1938 , advances in range science and management had a positive impact in the basin, as the Hamptons, in cooperation with the USFS, constructed fences, developed water sites, and undertook other projects to enhance pasture management. Between 1950 and 1984, the Round Top Ranch spent approximately $\$ 38$ per animal unit month ${ }^{4}$ (AUM) in the basin on range improvements. Improvements were so successful the Hamptons received range management awards from the Society for Range Management and the USFS.

The range improvements not only benefited livestock but also benefited wildlife, especially the elk (Cervus elaphus) population, which expanded tremendously during this period. Edward Hampton, Jr., an old man in 1973, remarked, "When I was a boy coming up into the basin, seeing an elk was an unusual sight. Now they run all over the place, especially before grazing season starts."

As years passed in the basin the rest of the USA experienced tremendous changes. The population grew and shifted from the farm and ranch to the city. Attitudes toward the land and its natural resources changed. People became concerned about air and water pollution, environmental quality, natural resource use, habitat protection, endangered species, public lands, and wilderness areas.

In the early 1960s, the rising national concern for the environment resulted in the Multiple Use-Sustained Yield Act being passed by Congress. This act put interests such as watershed protection, wildlife, fisheries, and recreation on an equal footing with grazing and timber production. In the late 1960s, the National Environmental Policy Act (NEPA) was passed; NEPA required government agencies to review the environmental impacts of any proposed action and make available to the public a written environmental assessment (EA) covering that review process. If the EA found significant impacts on the environment, NEPA required agencies to undertake an environmental impact study (EIS) documenting all environmental, economic, and social impacts of the proposed action, plus possible alternative actions, benefits, and costs. If the EA found no significant impacts, agencies were required to issue a Decision Notice and Finding of No Significant Impact outlining available alternatives and reasons for the agency's decision.

The first impact of these laws on Harmony Basin came in the late 1970s when the USFS began writing the Land and Resource Management Plan for the High Peaks National Forest (Exhibit 2). Released in 1983, the 2-inch (5-cm) thick document outlined objectives and goals for the forest over the following 10 to $15 \mathrm{yr}$ and included monitoring procedures, rangeland utilization standards, and key area concepts. ${ }^{5}$ The objectives and goals outlined in the forest plan followed multiple use concepts and, as required under NEPA, reflected public interests and priorities gathered from public meetings and written comments.

Livestock grazing systems and monitoring procedures were defined in the plan. Livestock were to graze under rest rotation, deferred grazing, or continuous grazing systems. Key monitoring areas were to be established in each allot-

\footnotetext{
${ }^{4}$ An animal unit month is the amount of forage required to maintain a mature cow or equivalent for $1 \mathrm{mo}$.

${ }^{5}$ For a discussion on standards and key areas, see Hall and Lindenmuth, 1998; and Sanders, 1998.
}

ment pasture and to be given a classification based on range conditions and timing of use. Cattle were only allowed to graze in a pasture until the utilization standard (percentage of forage removed) for that classification was met within the key area. When utilization on key areas exceeded the seasonal allowable use criteria, the following year's grazing would be cut until goals were meet.

The combined impacts of the Multiple Use-Sustained Yield Act, NEPA and the new forest plan finally hit like an earthquake in 1983 when the USFS released a new Allotment Management Plan (AMP) for the basin. Based on the utilization standards of the Forest Plan, the AMP imposed a $40 \%$ across-the-board reduction in grazing for a 6 -yr trial period.

The $40 \%$ cut in grazing was incomprehensible to the Hamptons. In their minds the basin was part of the ranch, it belonged to them, and consequently they had always worked to maintain and improve the basin rangelands. The family asked the USFS, "Wasn't overall rangeland health improving? How could 50 years of good range management suddenly lead to a $40 \%$ cut? Hadn't they won range management awards?" Then as reality sank in the family asked, "How can we keep enough cows to survive and still meet the demands of government?"

Caught between the need to survive and the pressures to comply, under protest, the Hamptons agreed to the AMP. But, because they really believed basin rangelands were in excellent condition, the Hamptons made only the smallest possible reductions in their cowherd. Most of the Hamptons' efforts under the new AMP went into scattering livestock to better hide the cows and their impacts. Cows were pushed 5 to 10 at a time into small clearings scattered in the timber, or hung on the sides of mountains to take advantage of hidden grazing. In the broken terrain and timber of a $177 \mathrm{~km}^{2}$ area, who could really tell if there were a few more cows than there should be?

While the ranch went about fighting its war for survival, the USFS undertook a 6-yr study to inventory resources and identify problem areas in the basin. In cooperation with the USFS, Chris Allison of the Wyoming Game and Fish Department also studied elk populations in the basin. Chris commented, "This is great opportunity to learn more about elk and elk habitat. I also want to make sure that elk don't get all the blame if problem areas are found."

During the study period, Tom West transferred into the area as USFS range conservationist for Harmony Basin. Upon his first visit to the basin in the fall of 1987, Tom said, "The devastation in the basin from cattle overgrazing is so widespread that, if it was up to me, all livestock grazing would stop for many years to come." Tom further commented that the USFS study underway at the time was a good first step toward documenting the definite downward trend in rangeland conditions across the basin.

The study, contained in the Environmental Assessment-Harmony Basin Allotment Management Plan (Exhibit 3 ), was released in interim form in 1988. The study reported that high altitude pastures were degraded and that upland aspen (Populus tremuloides Michx.) stands and riparian plant communities, especially willows (Salix sp.), failed to meet forest plan guidelines. The study also concluded basin streams showed severe impacts with wide, shallow channels 
and trampled, unstable stream banks. The study reported that elk use of the basin was well within allowed guidelines. In general, the allotment's livestock carrying capacity had previously been overestimated, with the result being a downward trend in resource condition. To reverse this trend, the study recommended complete rest of all pastures for $5 \mathrm{yr}$ or, failing that, a 50\% cut in cattle numbers and a 5-yr rest period for pastures above $2700 \mathrm{~m}(9000 \mathrm{ft})$ in altitude, followed by restocking with domestic sheep.

The USFS study gathered both praise and criticism. Praise came from within the USFS and environmental community as individuals touted the study as an excellent example of the thoroughness and professionalism of USFS in attempting to protect the environment. Criticism, on the other hand, came from outside the USFS as people like the Hamptons, local agricultural and business interests, and Wyoming state politicians disagreed with the study's methods and conclusions. These groups accused the USFS of carrying out the study to justify a perceived anticow bias.

In an attempt to deal with the criticism, the USFS asked Tim Pace and John O'Day, professors in the Department of Range Science at the University of Wyoming, to ride the allotment in late summer 1989 and view the areas the study was based on. The professors reviewed the methodology and conclusions of the study and found serious flaws based on what they had seen during the ride. Pace and O'Day reported that the USFS study presented unfounded problems with high-altitude pastures, exaggerated concerns in riparian areas, and assigned blame to cattle for damage that might have been caused by elk. The professors reported that rangeland conditions in the basin were on an upward trend and stocking rate reductions were not needed. The few problem areas that existed were isolated and could be easily fixed by small changes in current management practices.

Regardless of the criticism, the USFS wrote and released an Environmental Assessment-Harmony Basin Allotment Management Plan (EA) (Exhibit 3) in 1990 that was based on the controversial USFS study. The EA outlined the study results and presented five possible management alternatives. The alternatives were: (i) no action, leave the 1983 AMP in effect; (ii) reinstate pre-1983 cattle numbers and continue management under the current AMP; (iii) permanent 50\% cut in AUMs to adjust the stocking rate, plus 5 yr rest above the $2700 \mathrm{~m}$ (9000 ft) elevation then restock with sheep; (iv) $70 \%$ cut to adjust stocking rate on entire allotment; and (v) convert entire allotment to sheep grazing, along with a $50 \%$ cut to adjust stocking rate.

Upon release of the EA, rumors began to fly that the USFS was going to recommend Alternative iii. Under this plan, the number of cattle grazing from 1 July to 10 October would decrease from 1707 to 718 head, and 1200 sheep would be allowed to graze for $45 \mathrm{~d}$ from 15 July to 1 September.

For the Hampton family, the rumored cuts were too much. A drought in 1988 had already forced a reduction in the ranch cow herd and they were tired of fighting the USFS. Instead of getting back into the sheep business and reducing their cow herd even further, the Hamptons put the ranch up for sale.

In early 1991, Martha and Jake Sowers became interested in purchasing the Round Top Ranch. The Sowers inquired about the rumored grazing plan and were assured by Tom West of the USFS that although $50 \%$ cuts in grazing were possible, lesser cuts were more likely-especially if the Sowers would commit to proper management of their cattle in the basin.

Based on these assurances, the Sowers took possession of the Round Top Ranch, believing it to have a carrying capacity of 1500 cows. Shortly thereafter, the Sowers received from the USFS a Decision Notice and Finding of No Significant Impact (Exhibit 4) written by Tom West and signed by Lance Ferris, Harmony Basin district ranger. The notice outlined the alternatives available under the EA and specified Alternative iii as the preferred choice.

Upon receipt of the notice, the Sowers were very upset. Under Alternative iii they faced having summer pasture for only 518 cows instead of the 1307 cows they had planned for, and they faced being in the sheep business in $5 \mathrm{yr}$, something they knew nothing about. They also estimated that the carrying capacity of the Round Top Ranch would fall from 1500 to 1000 head of cattle, and since the value of a ranch was based on its carrying capacity, they stood to lose almost one-third of the real estate value.

While Martha and Jake Sowers were upset about the notice, the Pratt family, who had a permit for 300 cows in the basin, was in a state of shock. Their only source of income was the ranch's 300 cows and the only summer pasture they had was in the basin. The Pratt ranch, along with the neighboring Moon Ranch who had a basin permit for 100 cows, had been grazing cows in the basin for as long as the Round Top Ranch, but had escaped the earlier cuts. Under Alternative iii, they faced the same permanent $50 \%$ cut in summer grazing as the Round Top did. Unlike the larger Round Top Ranch and Moon Ranch, the Pratt Ranch only had 300 cows and was already as small as a ranch could get and still support a family.

After researching the issues and talking to the Moons, the Pratts, and Tim Pace and John O'Day, Martha felt the USFS was committing a grave injustice against the ranches. Martha asked, "How is it possible that $50 \mathrm{yr}$ of management, all under the direction of the Forest Service, could suddenly be so wrong that a $50 \%$ cut is required?" She also asked, "Why is it that the opinions of two men, both experts in range management, differ so much from Forest Service opinions?" Martha said, "If I thought the Forest Service was really right about range conditions on the allotment I would be happy to cut cattle numbers for a while, but I don't know who to believe and I certainly don't think any permanent cuts are warranted."

Determined to slow down implementation of Alternative iii until her questions could be answered, Martha found that her first legal recourse was through the USFS's internal appeals process with Sid Barnes, the High Peaks National Forest supervisor, as reviewing officer. On behalf of the Harmony Basin permittees, Martha hired a lawyer and appealed the USFS decision before Sid Barnes. Martha said, "I think grazing permits across the west are being cut because of an anticow political agenda of individuals within the Forest Service and because most small ranches don't have the resources needed to fight back against a giant government bureaucracy like the Forest Service. I do have the resources, and I am going to fight, and I will fight on behalf 
of all those who can't. I consider it a worthwhile contribution to cattle ranching in Wyoming."

After receiving the Notice of Permittees Appeal and Statement of Reasons (Exhibit 5), outlining the permittees' arguments, Sid Barnes granted a stay of the decision. At the permittees' request, Sid Barnes committed the USFS to participate in a Coordinated Resource Management (CRM) group as directed under a Memorandum of Understanding that had been entered into in 1982 with the Bureau of Land Management, the Natural Resource Conservation Service, and the Wyoming Cooperative Extension Service. The memorandum had made CRM the preferred natural resource planning process in Wyoming for the agencies involved.

The CRM group was charged with formulating a longterm grazing management plan for the basin that would: (i) remedy problems and ensure that the allotment met the standards and guidelines mandated in the Land and Resource Management Plan for the High Peaks National Forest (Exhibit 2), and (ii) minimize the negative economic and social impacts outlined by the permittees. These plans would then be used by the USFS to help write an AMP for Harmony Basin.

Once agreement had been reached to form the CRM group, invitations were sent to groups and individuals who might have an interest in participating, including environmental groups and federal and state government agencies. After allowing time for everyone to reply, the Harmony Basin CRM committee was formed with the members listed in Appendix 1.

\section{The Conflict}

As preparations were being made for the first Harmony Basin CRM meeting, participants were very vocal about their positions and concerns on a variety of different issues. One position they all seemed to hold centered on protecting the environment within the basin. Each individual, in their own way, said they wanted to conserve and sustain healthy rangelands, forests, and streams in the basin for multiple uses. They personally enjoyed the beauty and natural wonders of the basin through participation in a variety of recreational activities like viewing wildlife, fishing and hunting, summer backpacking, or horse-packing trips and photography.

All future participants, however, did take different positions on what protecting the environment meant and how that protection could best be achieved. The positions, concerns, and personalities of these individuals are portrayed in Exhibit 7. The widest difference in positions, though, was between the permittees, led by Martha Sowers, and the USFS represented by Tom West and Lance Ferris.

Tom West made it clear that his position was absolutely for a reduction in grazing and the conversion of high altitude pastures to sheep as outlined in Alternative iii. Tom said, "I have been convinced from my first visit to the basin back in the fall of 1987 that overall range conditions were declining rapidly and that only drastic measures could reverse the trend. Further visits since that time have only reinforced my original impression. In fact, I still think the best route would be to eliminate all livestock grazing for a 5 or 10 -year period." Tom West was also heard to say, "I grew up on a
Wyoming ranch so I have a personal interest in ranching, but my family survived without government subsidized grazing on Forest Service land, so these ranches should be able to do the same." Tom added that he didn't really want every single cow off of the forest, he just thought that ranching interests should be subordinate to the needs and interests of the national forest as the USFS defined them. "After all," Tom said, "when it comes to the Harmony Basin Grazing Allotment, I and my colleagues are the only real experts involved."

The permittees, on the other hand, took the position that the pre-1983 grazing plan for Harmony Basin (including allotment and pasture boundaries, grazing seasons, fencing, water developments, and permitted numbers of cows) was a proven, successful, balanced, and sustainable system based on $>50 \mathrm{yr}$ of experience. According to the permittees, this plan balanced all parts of the ecosystem [national forest lands, private pastures, irrigated hay meadows, Bureau of Land Management (BLM) desert grazing allotments, climate, plant and animal communities, and watersheds] as well as the social and economic structures ${ }^{6}$ of the Harmony Basin area. Changing the grazing system, according to the permittees, would result in tremendous negative economic and social impacts on them, on the value of their ranches and on area residents and communities, all with no appreciable gains in rangeland conditions in Harmony Basin.

Martha Sowers added this comment, "The grazing system in effect up to 1983 worked and that hasn't changed. The only thing that has changed is the political agenda of the Forest Service." Martha also said, "I love the Round Top Ranch and don't want any damage to the environment in the basin. If I thought the Forest Service's decision was based on sound grazing management principles, I wouldn't protest. At every turn it seems that the Forest Service has bent data to fit its agenda, lied about its motives, and allowed local employees to make decisions based merely on their personal opinions." Martha finished by saying, "I have come to see this fight as a battle against government tyranny and intrusion into my life and the lives of all ranchers in the Rocky Mountains."

When asked where he stood, Lance Ferris said, "In my opinion the Forest Service is the only entity involved in the Harmony Basin that is capable of making an informed, rational decision concerning management of the basin. Local and state interests have shown too much of a willingness to sell out the future for the chance of making a dollar today. And besides that," Lance added, "since the Forest Service is the only legally responsible party involved with Harmony Basin, we will make all the decisions in the endnot necessarily because we want to, but because we have too."

Behind the rhetoric, positions were based on technical issues relating to the establishment of key areas and the application of utilization standards as outlined in the Land and Resource Management Plan for the High Peaks National Forest (Exhibit 3). The USFS insisted utilization standards were not being met in key areas. Tom West said, "The goal is to have all basin rangeland in 'satisfactory"

\footnotetext{
${ }^{6}$ For a discussion on the economic impacts of public grazing policy, see Fletcher et al., 1998; VanTassell and Richardson, 1998; and VanTassell et al., 1997.
} 
condition by the year 2000 . We always try to locate key areas so our measurements will monitor each pasture where cattle make the greatest impacts."

The permittees took the position that the standards were already being met in most pastures and the problems that existed could be easily handled with small changes in current pasture management practices. In their opinion, the utilization standards applied to average range conditions within each pasture. Key areas, therefore, should be in average use areas to measure average use. Darren Younger, the Round Top Ranch manager, explained, "This is mountain country. Cattle have to move from pasture to pasture, and even within pastures, by trails to get through the rocks and trees. If you set up and take your measurements close to a trail, you always get excessive use. There's no way around it. We've tried moving gates and trails in order to move the cattle in different patterns. But when we do, the Forest Service moves their key area so they can measure close to the new trail."

Another concerning technical issue dealt with elk. Chris Allison, of the Wyoming Game and Fish Department, joined the USFS in taking the position that elk grazing should not be an issue. According to Chris, elk population counts and monitoring measurements showed that elk numbers were at allowable levels and use of available forage was $<10 \%$. Their monitoring also showed that the use of forage by elk in the spring had not exceeded the $25 \%$ allowed under agreements between the USFS and the Wyoming Game and Fish Department.

The permittees did not just take a position against the population numbers quoted by the USFS, but were concerned with the methods used to report elk forage use. Jason Sills, who was the range conservationist for the Round Top Ranch said, "It's interesting that the Forest Service insists on measuring the worst cattle impacts, but then will turn around and only report average elk forage use." Jason added, "The fact is, elk will camp out on the best parts of a pasture just like cows, and when they do the impacts look the same, only the hoof prints are different." Darren Younger commented, "The Forest Service doesn't want to accurately measure elk forage use anyway, because if they did, they would have to admit that there are a lot more elk running around these hills than allowed under their own regulations."

\section{Finding a Solution}

Following the public airing of positions, the Harmony Basin CRM group was scheduled to meet and formulate long-term grazing management plans for the Harmony Basin Grazing Allotment. These plans would serve as the basis for future Harmony Basin AMPs.

\section{CASE EXHIBITS}

Many of the exhibits are several pages in length and may be assigned as reading material at the instructor's discretion, depending on the background of the students and intent of the learning exercise.

Exhibit 1: Allotment Description (8 pages). This exhibit contains a description written by the USFS of the geographical and biological characteristics of the Harmony
Basin Grazing Allotment and includes pasture names and descriptions.

Exhibit 2: Land and Resource Management Plan for the High Peaks National Forest (9 pages). This exhibit contains an abridged copy of the 1983 Forest Plan for the High Peaks National Forest. The plan establishes management direction, goals, and objectives for the High Peaks National Forest and specifies standards and guidelines as well as the approximate timing and vicinity of practices necessary to achieve goals and objectives. It also establishes monitoring and evaluation requirements needed to measure the effectiveness of all efforts carried out under the plan.

Exhibit 3: Environmental Assessment-Harmony Basin Allotment Management Plan (27 pages). This exhibit contains a copy of the Environmental Assessment published by the USFS in 1990. This document presents alternative management plans considered by the USFS to bring management of grazing in the basin into compliance with the Forest Plan and the impacts of these revisions.

Exhibit 4: Decision Notice and Finding of No Significant Impact (10 pages). This exhibit contains a copy of the Decision Notice issued by the USFS in 1991 announcing the USFS's decision on an Allotment Management Plan for the Harmony Basin Grazing Allotment. The document also reviews the alternative plans considered in the Environmental Assessment and the reasoning behind the choice made.

Exhibit 5: Notice of Permittees Appeal and Statement of Reasons (6 pages). This exhibit contains a copy of the appeal written by Martha Sowers' attorneys and submitted to Sid Barnes, supervisor of the High Peaks National Forest in protest of the 1991 Decision Notice. The document outlines Martha's arguments against letting the Decision Notice stand.

Exhibit 6: Report Pertaining to the Ride on the Allotment, 17-18 Aug. 1989 (15 pages). This exhibit contains a copy of the report submitted to the USFS at their request by Tim Pace and John O'Day, professors in the Department of Range Management, University of Wyoming. This report contains the concerns and criticisms of Pace and O'Day pertaining to the 6-yr study (1983-1989) carried out by the USFS that served as the basis for both the Environmental Assessment published in 1990 and the Decision Notice issued in 1991.

Exhibit 7: Personality Profiles of the Harmony Basin CRM Group (22 pages). This exhibit contains basic personal profiles of all members of the Harmony Basin Coordinated Resource Management Group as listed in Appendix 1. These personal profiles can be used for an inclass role-play where students can discuss the case as if they were actual participants with a personal interest in the case.

Exhibit 8: Wyoming CRM: Enhancing Our Environment (18 pages). This exhibit is a brochure written by Scott E. Cotton and Ann C. Cotton for the Wyoming Department of Agriculture. The brochure contains an introduction and history of CRM, examples of CRM groups in Wyoming, a discussion of the value of CRM, a summary of CRM, and a copy of CRM guidelines. 


\section{INTERPRETIVE NOTE}

\section{Case Objectives}

Through the deliberation and discussion of this case, participants will:

- Gain insight into the varied interest groups, individuals, and positions that underlie this and similar natural resource conflicts.

- Experience the problems and frustrations involved in solving natural resource conflicts.

- Learn fundamental elements of the CRM process and guidelines, and have an opportunity to discover the need for-along with the advantages and disadvantages - of the CRM process.

- Have the opportunity to discuss the economic and social impacts that changes in USFS management of a grazing allotment can have on local ranch families, on the value of their ranches, on area residents, and on area communities.

- Understand the need for using well conceived methods of collecting range management information.

- Gain experience with the type of documents used by the USFS in managing a grazing allotment.

- Have the opportunity to improve their communication and decision making skills.

\section{Use of the Case}

This case was originally developed for use in interdisciplinary capstone courses for senior-level range management, agricultural economics, and animal science students, but will also be of value to extension educators, professionals, and others concerned with learning about and discussing natural resource conflicts in the Rocky Mountains.

While valuable as a decision case for in-class discussions, the case was designed to be used for an in-class role play where students take on the identity, interests, and personality of individuals participating in the Harmony Basin CRM group. Through the role-play, students have the opportunity to personally experience the frustrations and triumphs of solving a natural resource conflict.

The case has been used once in class as a role-play. Three periods were dedicated to the case. During the first period, the CRM process was introduced and students received the roles they would play. During the second and third periods, students played out their roles while participating in a CRM meeting with a facilitator trained in the CRM process. During the second period, students argued issues while exploring their roles. They were then led in a consensus and team building exercise by the CRM facilitator. In the third period, the students attempted to deal with issues while trying to develop a management plan for the basin. During the last part of the third period, students were asked to fill out a short survey covering their impressions of the case and the role-play format.

Student comments about the strengths of the case ranged from, "Showed how CRM works" and "great role playing" to "This is the only day of lab/class that I have wanted to go to." When asked how the case could be more effective and useful, students wrote, "More time should be allowed to actually hammer out solutions..." and, "More background information. More preparation time." During class students showed a wider range of reactions ranging from frustration with the lack of information (it was also obvious that some students had not read the information that was available) and anger at being told, "Use your imagination and play the role the way you want." Many students welcomed the chance to defend their character's position.

Given student comments and the high level of class participation, the case objectives appeared to be met. Students were more aware of the issues and frustrations involved in natural resource conflicts. They had learned about the CRM process and, most importantly, come to realize why CRM is needed. They become familiar with USFS documents, discussed economic and social impacts, and internalized the need for sound methodology.

\section{Discussion Questions}

The questions that follow are examples of questions that could be used to stimulate discussion of issues in the case.

1. Who do you think are the main antagonists in this case? Why is the conflict so intense between these antagonists?

The major conflict exists between Martha and Jake Sowers (permittees) and Tom West (USFS). The conflict becomes intense because of their strong personalities and commitment to their individual causes.

2. What do you think is the main point of conflict in this case? What are the secondary points of conflict?

In a technical sense, the main point of conflict is over the general trend in range conditions. The USFS is convinced that overall range conditions in the basin are declining rapidly and only drastic measures - such as the $50 \%$ cut in grazing - can reverse the trend. The permittees are convinced that the general trend is up and that forest goals can be reached using historic cattle numbers and seasons with only small changes in present grazing practices. But, as it is with many public land issues, the actual conflict is of a political nature. The USFS claims their job is to set the rules, establish study procedures, gather data, make the judgements, decide final outcomes, and if arguments arise, act as judge and jury in the appeals process. The permittees, on the other hand, argue that USFS actions cannot be arbitrary and capricious (i.e., based on personal opinions and political agendas) but must hold up to public review. Secondary points of conflict are:

- Technical issues relating to the establishment of key areas and monitoring of grazing impacts.

- Wildlife vs. livestock on public lands and the effects of high wildlife populations.

- Local vs. federal decision making on public lands.

- Deciding who pays for improving rangeland conditions, the rancher or the public.

- Private property rights associated with holding federal grazing permits and the taking of private property for public use without just compensation under the Fifth Amendment to the U.S. Constitution in regard to economic losses claimed by the permittees.

3. Are there any issues that members of the CRM agree on? Why is it important to recognize these points of agreement? 
All CRM participants want to protect and preserve rangelands within the basin. Points of agreement are important because they serve as a foundation where people can begin to communicate. The CRM process begins by finding points of agreement, then builds consensus while focusing on needs instead of positions.

4. With all the monitoring and study that has occurred on this allotment, why do you think there is still a conflict over grazing management in the basin?

The basic conflict is still present because the overall trend in basin range conditions has never been clearly determined. The USFS just assumed that the trend was down, while the permittees just assumed that the trend was up. The monitoring and study that has occurred started with one assumption or the other, leaving the basic question relating to trend, unanswered. In addition, conflict is still present because of disagreements over the definition and use of key areas where utilization measurements are taken and the forage elk are consuming. If elk are a significant contributing factor, then even with the complete removal of cattle, utilization standards won't be met.

\section{How do you think individual perspectives and val- ues impact this conflict?}

Tom West's beliefs toward rangeland trend, livestock on public lands, subsidized grazing for ranchers, and wildlife impact this case by narrowing the problem and solutions he is willing to consider. Martha Sowers' beliefs about the USFS and government, in general, were the motivating force behind her to appeal of the decisions made by the USFS and her impetus in pursuing the CRM process.

6. What do you see in the CRM method for resolving disputes such as Harmony Basin?

The CRM method, as outlined in Appendix 2, changes the focus of attention from conflict to common goals. This encourages communication, builds trust and understanding, and ultimately leads to winning solutions for all involved, especially for the natural resource in question.

\section{APPENDIX 1}

\section{Harmony Basin Coordinated Resource Management Committee Members}

\begin{tabular}{|c|c|}
\hline Committee member & Association or position \\
\hline Martha Sowers & Owner, Round Top Ranch \\
\hline Jake Sowers & Owner, Round Top Ranch \\
\hline Tom West & Harmony Basin Range Conservationist, USF \\
\hline Lance Ferris & Harmony Basin District Ranger, USFS \\
\hline Bob Thayer & $\begin{array}{l}\text { Range Conservationist, Natural Resource } \\
\text { Conservation Service }\end{array}$ \\
\hline Sharon Rogers & $\begin{array}{l}\text { Range Conservationist, Bureau of Land } \\
\text { Management }\end{array}$ \\
\hline Chris Allison & $\begin{array}{l}\text { Wildlife Biologist, Wyoming Game \& Fish } \\
\text { Department }\end{array}$ \\
\hline Kelly Buck & $\begin{array}{l}\text { Biology Teacher, Harmony Community } \\
\text { College }\end{array}$ \\
\hline Lloyd Moon & Owner, Moon Ranch \\
\hline Mike and Sue Pratt & Owners, Pratt Ranch \\
\hline Chuck Overman & $\begin{array}{l}\text { University of Wyoming Cooperative } \\
\text { Extension Service Agent, Harmony } \\
\text { County }\end{array}$ \\
\hline John Jackson & $\begin{array}{l}\text { Professor, University of Wyoming Range } \\
\text { Department }\end{array}$ \\
\hline Darren Your & Ranch Manager, Round Top Ranch \\
\hline Jason Sills & Range Conservationist, Round Top Ranch \\
\hline
\end{tabular}

\section{APPENDIX 2}

\section{Coordinated Resource Management (CRM)}

First conceived in the early 1950s, CRM has become the method of choice in bringing together dedicated people from private, public, and special interest backgrounds to effectively manage natural resources. Officially recognized in 1982 as the natural resource planning process for Wyoming, CRM operates with the following guidelines (Cotton and Cotton, 1995)

1. CRM is strictly a voluntary program.

2. It should be landowner initiated with landowner leadership.

3. All interested agencies, organizations, and interest groups must be involved.

4. The CRM committee should be facilitated by a knowledgeable neutral party.

5. Ground rules establishing rules of behavior and conduct need to be set.

6. Common goals must be developed at the very beginning of the CRM process.

7. All members must have the authority to make decisions for their respective entities.

8. CRM operates under management by consensus

9. Focus is on needs vs. position.

10. Create a team by developing understanding and trust among committee members.

11. All members must be committed to the process

12. Management objectives must be developed and prioritized.

13. Monitor for baseline data, and for data showing successes or failures of new management practices, to facilitate adjustments that will achieve management objectives.

14. A CRM plan must have flexibility built in to allow for changing conditions.

\section{REFERENCES}

Borman, M.M., and D.E. Johnson. 1990. Evolution of grazing and land tenure policies on public lands. Rangelands 12(4):203-206.

Cotton, S.E., and A.C. Cotton. 1995. Wyoming CRM: Enhancing our environment. Wyoming Dep. of Agric., Cheyenne, WY.

Cramer, L.A., J.J. Kennedy, R.S. Krannich, and T.M. Quigley. 1993. Changing Forest Service values and their implications for land management decisions affecting resource dependent communities. Rural Soc. 58(3):475-491.

Fletcher, R.R., G.W. Borden, T.R. Harris, D.T. Taylor, and B.R. Moline. 1998. Comparison of economic impacts from public-land-based tourism and grazing: A case study. p. 57-70. In Stubble height and utilization measurements: Uses and misuses. Western Regional Research Publ. Agric. Exp. Stn. Bull. 682. Oregon State Univ., Corvallis, OR.

Hage, W. 1994. Storm over rangelands: Private rights in federal lands. 3rd ed. Free Enterprise Press, Bellevue, WA.

Hall, F.C., and R. Lindenmuth. 1998. Developing and achieving management objectives on national forest system lands. p. 47-49. In Stubble height and utilization measurements: Uses and misuses. Western Regional Research Publ. Agric. Exp. Stn. Bull. 682. Oregon State Univ., Corvallis, OR.

Holechek, J.L., R.D. Pieper, and C.H. Herbel. 1989. Range management: Principles and practices. Prentice Hall, Englewood Cliffs, NJ.

Lundburg, F.L. 1980. Public lands and public policy. Rangelands 2(5): 199-200.

Ross, J.V.H. 1984. Managing the public rangelands: 50 years since the Taylor Grazing Act. Rangelands 6(4):147-151.

Sanders, K.D. 1998. Utilization standards: The quandary revisited. p. 3-8. In Stubble height and utilization measurements: Uses and misuses. Western Regional Research Publ. Agric. Exp. Stn. Bull. 682. Oregon State Univ., Corvallis, OR.

VanTassell, L.W., and J.W. Richardson. 1998. Impact of federal grazing reductions on wyoming ranches. p. 50-56. In Stubble height and utilization measurements: Uses and misuses. Western Regional Research Publ. Agric. Exp. Stn. Bull. 682. Oregon State Univ., Corvallis, OR.

VanTassell, L.W., L.A. Torell, N.R. Rimbey, and E.T. Bartlett. 1997. Comparison of forage value on private and public grazing leases. $\mathrm{J}$ Range Manage. 50:300-306. 